NBER WORKING PAPER SERIES

\title{
THE EFFECTS OF TAXES ON MARKET RESPONSES TO DIVIDEND ANNOUNCEMENTS AND PAYMENTS: \\ WHAT CAN WE LEARN FROM THE 2003 DIVIDEND TAX CUT?
}

\author{
Raj Chetty \\ Joseph Rosenberg \\ Emmanuel Saez \\ Working Paper 11452 \\ http://www.nber.org/papers/w11452 \\ NATIONAL BUREAU OF ECONOMIC RESEARCH \\ 1050 Massachusetts Avenue \\ Cambridge, MA 02138 \\ June 2005
}

Raj Chetty, chetty@econ.berkeley.edu, Joe Rosenberg, jwr@econ.berkeley.edu, Emmanuel Saez, saez@econ.berkeley.edu, University of California, Department of Economics, 549 Evans Hall, \#3880, Berkeley, CA 94720. We thank Alan Auerbach, Douglas Bernheim, Gustavo Grullon, Francisco PerezGonzalez, James Poterba, Douglas Skinner, and Joel Slemrod for helpful comments and discussions. Financial support from NSF Grant SAES-0134946 and the Sloan Foundation is gratefully acknowledged. The views expressed herein are those of the author(s) and do not necessarily reflect the views of the National Bureau of Economic Research.

(C)2005 by Raj Chetty, Joseph Rosenberg, and Emmanuel Saez. All rights reserved. Short sections of text, not to exceed two paragraphs, may be quoted without explicit permission provided that full credit, including (C) notice, is given to the source. 
The Effects of Taxes on Market Responses to Dividend Announcements and Payments: What Can We Learn from the 2003 Dividend Tax Cut?

Raj Chetty, Joseph Rosenberg, and Emmanuel Saez

NBER Working Paper No. 11452

June 2005

JEL No. G1, H3

\section{ABSTRACT}

This paper investigates the effects of capital gains and dividend taxes on excess returns around announcements of dividend increases and ex-dividend days for U.S. corporations. Consistent with standard no-arbitrage conditions, we find that the ex-dividend day premium increased from 2002 to 2004 when the dividend tax rate was cut. Consistent with the signalling theory of dividends, we also find that the excess return for dividend increase announcements went down from 2002 to 2004. However, these findings are very sensitive to the years chosen for the pre-reform control period. Semi-parametric graphical analysis using data since 1962 shows that the relationship between tax rates and ex-day and announcement day premia is very fragile and sensitive to sample period choices. Strong year-to-year fluctuations in the ex-day and announcement day premia greatly reduce statistical power, making it impossible to credibly detect responses even around large tax reforms. The important non-tax factors affecting these premia must therefore be understood before progress can be made in evaluating the role of taxation in market responses.

Raj Chetty

Department of Economics

UC Berkeley

521 Evans Hall \#3880

Berkeley, CA 94720

and NBER

chetty@econ.berkeley.edu
Joseph Rosenberg

Department of Economics

UC Berkeley

521 Evans Hall \#3880

Berkeley, CA 94720

jwr@econ.berkeley.edu
Emmanuel Saez

University of California

549 Evans Hall \#3880

Berkeley, CA 94720

and NBER

saez@econ.berkeley.edu 


\section{Introduction}

There is a long-standing debate in the finance and public economics literatures about the role of taxation in corporate dividend payout policies. Starting with Elton and Gruber (1970), researchers have investigated whether the tax-favored treatment of capital gains relative to dividends affects excess returns on ex-dividend and announcement dates. ${ }^{1}$ The answers to these questions can potentially shed light on the efficiency consequences of dividend taxation as well as the reasons why corporations pay dividends despite their tax disadvantage, as explained in greater detail below. ${ }^{2}$ Despite substantial research, the empirical literature on this topic remains controversial (see Allen and Michaely, 2003 for a recent survey).

This paper proposes to use the 2003 dividend tax cut in the United States to cast light on these issues. The 2003 tax cut, part of the Jobs and Growth Tax Relief Reconciliation Act of 2003, eliminated most of the tax disadvantage of dividends relative to capital gains. Blouin et al. (2004) and Chetty and Saez (2005) have shown that the reform indeed raised dividend payments significantly, and in particular induced many firms to initiate dividend payments. Here, we aim to investigate whether this reform had a significant effect on the ex-day and announcement day price behavior as well. Consistent with the no-arbitrage conditions in standard models, we find that the ex-dividend day premium increased from 2002 to 2004 when the dividend tax rate was cut. Consistent with the signalling theory of dividends (and in contradiction with the agency models of dividends), we find that the excess return for dividend increase announcements went down from 2002 to 2004.

In order to have a broader perspective and assess with greater confidence whether there was a sharp change after 2003, we construct a time series of ex-day price changes and excess returns around dividend increase announcements at an annual level since 1962 (the first year daily price data becomes available) for all companies in the Center for Research in Security Prices (CRSP) data. To the best of our knowledge, despite the large number of studies on these issues, such a time series had not been constructed and examined in prior work. A number of useful findings emerge from this long-run analysis.

First, we find that there is substantial year to year volatility in the annual time series of

\footnotetext{
${ }^{1}$ The ex-day is the date at which the dividend leaves the share.

${ }^{2}$ Note, however, that ex-dividend day price behavior does not allow us to distinguish the old view from the new view of dividend payout policies (see Auerbach, 1983).
} 
excess returns around both the ex-day and announcement day that is unrelated to tax changes. The annual variation in the time series is not simply due to idiosyncratic firm level noise, since this variation should be averaged out given the very large samples we are using. Powerful year effects (aggregate shocks) unrelated to taxes are responsible for this pattern. Unfortunately, the time series pattern is non-monotonic and therefore is unlikely to be explained by a single change (such as the elimination of discrete pricing in the U.S. stock market) or by a gradual trend (such as the rise of the share of corporate stocks owned by pension funds). Moreover, we are unable to find a set of covariates that had much explanatory power in smoothing the aggregate fluctuations. A simple power analysis shows that even the effects of large tax reforms would be difficult to detect given the aggregate volatility of the series. We conclude that one should be careful when comparing individual years (e.g. around a reform) to detect a tax effect. The 2003 tax change illustrates this point well. As mentioned above, the ex-day premium pattern suggests a strong tax effect if one compares 2002 to 2004, but a placebo test comparing 2002 to 2000 would produce a false positive.

Second, the long run time pattern of the ex-day price behavior does not follow the long run reduction in the disadvantage of capital gains versus dividends. Overall, it is therefore difficult to detect any robust pattern that one could attribute with confidence to a tax effect along the lines that Elton and Gruber (1970) originally proposed. More work is needed to test the various theories of ex-day price changes using the full time series evidence rather than a focus on particular years, as has been the tradition in the literature.

Third, consistent with the empirical results of the influential study by Bernheim and Wantz (1995), we find that the overall effect of dividend increase announcements on prices has declined over time while the tax disadvantage of dividends has fallen. This finding supports the signalling theory of dividend payments, which argues that firms pay dividends despite their tax disadvantage in order to send a signal to the market about their profitability. However, again because of the large year to year variation in the time series of price effects, it is impossible to detect systematic effects around the major tax reforms in the United States since 1962, including the 2003 dividend tax cut. Therefore, the conclusion supporting the signalling theory rests on the strong assumption that no other long term trend has driven the price effects down. It is, however, quite plausible that factors other than tax changes (such as the increased availability of information about corporate activities) could have caused the secular 
decline in announcement premia.

Our general assessment is therefore that little knowledge about tax effects can be gained even from large reforms such as the 2003 tax cut because of the extreme aggregate volatility in the time series of the data. The estimates of prior studies - which obtain significant results by making strong assumptions about the functional form or statistical properties of the error terms in regressions or by focusing on particular windows around tax changes - should therefore be viewed with caution. To be clear, we are not advocating time-series analysis instead of focusing on sharp tax experiments. Rather, we argue that credible empirical analysis requires examination of whether the changes in excess returns around a tax experiment are exceptional relative to the fluctuations in a long time series.

The remainder of the paper is organized as follows. Section 2 presents the conceptual framework and discusses previous work. Section 3 describes the data and our methodology. Sections 4 and 5 present the empirical results on ex-dividend premia and dividend increase announcements respectively. Section 6 describes the main methodological conclusions that we draw from this analysis.

\section{Conceptual Framework and Previous Work}

Dividend payments affect short-term stock price behavior in two ways. First, firms announce dividend payments about 4 to 6 weeks before the actual payment is made. Announcements of dividend initiations (a firm starting to pay dividends) or dividend increases (for a firm already paying dividends) are generally viewed as good news and generate on average a positive excess return around the announcement date (see Allen and Michaely, 2003 for a survey). This is because increases in regular dividend payments are perceived by the market as a strong commitment to pay more dividends in the future. Historically, regular dividend payments (in general quarterly, but sometimes annual or semi-annual) tend to be very smooth: Firms do not increase their dividend payments very often, and are extremely reluctant to decrease or terminate dividend payments.

Second, when the dividend is paid, the book value of the corporation is reduced by the amount paid out, which generates a negative excess return around the payment event. More precisely, when a corporation announces a dividend payment, it sets two key dates: the ex- 
dividend date and the payment date. The payment date is the date when the corporation effectively pays out the dividend and is in general about 2 weeks after the ex-dividend date. Dividends, however, are paid out to stockholders according to stock ownership just before the ex-dividend date (and not according to stock ownership at the time of payment). In other words, a stockholder is entitled to the dividend payment if and only if he owns the stock just before the start of the ex-dividend day. ${ }^{3}$ Therefore, we should expect a drop in price between the end of day preceding the ex-day (sometimes called the cum-day to mean that the stock is trading with the dividend on that day) and the beginning of the ex-day because those buying the stock after the beginning of the ex-day are no longer entitled to the dividend payment.

The effects of dividend announcements and ex-dates on stock prices can be nicely illustrated with the extremely large special dividend payment of $\$ 3$ per share made by Microsoft at the end of 2004. This special dividend (along with a doubling of the regular dividend) was announced on July 20, 2004. ${ }^{4}$ One can clearly see on the figure that the share price rose quickly in the days surrounding the announcement (illustrated with vertical lines in Figure 1). This jump represents the "excess return" around the announcement date, which we define formally below. The ex-dividend day for the special dividend was set as November 15, 2004. Hence all individuals and institutions owning Microsoft shares before the start of November 15, 2004 were entitled to a $\$ 3$ dividend per share. The sharp drop in the price at this time is consistent with the negative excess return that we expect around the ex-date. Finally, dividend payments were made by Microsoft to those shareholders on December 2, 2004 (irrespective of whether they had sold their stock after November 15).

Our analysis roughly seeks to answer the question: "How would the excess returns around the announcement and ex-dates in the Microsoft figure have differed if these events had occurred prior to the 2003 tax cut?" We answer this question essentially by averaging excess returns around the ex-day and announcement dates for many firms and comparing the means during different tax regimes. Since the timing of the tax changes is quite important for our analysis, it will be helpful to review the details of the reform here. The Jobs and Growth Tax Relief Reconciliation Act of 2003 introduced favorable treatment for individual dividend

\footnotetext{
${ }^{3}$ An individual purchasing the stock between the ex-day and payment day would not receive the dividend, but the former owner would.

${ }^{4}$ At the same day, Microsoft announced an increase in its regular dividend payment: Microsoft had previously paid an annual dividend of 16 cents per share and announced that it was switching to quarterly payments of 8 cents per share, effectively doubling its regular dividend payments.
} 
income whereby dividends are taxed at a rate of 15 percent instead of facing the regular progressive individual income tax schedule with a top rate of 35 percent. ${ }^{5}$ The reform was officially signed into law on May 28, 2003, but was first proposed by the Bush administration on January $7,2003 .{ }^{6}$ The tax cut on dividend income was made retroactive to the beginning of 2003. Therefore, during the first two quarters of 2003, corporations knew that dividends would face lower taxes with some probability. President Bush initially proposed a full exemption of dividend taxation at the individual level, potentially biasing pre-enactment expectations toward a larger tax reduction than what actually occurred. The tax rate on long-term realized capital gains was also reduced by the Jobs and Growth Tax Relief Reconciliation Act of 2003, but the reduction was smaller from $20 \%$ to $15 \%$, and applied only to capital gains realized after May 28,2003 . Thus, this change reduced significantly the tax disadvantage of dividends relative to capital gains. The tax cut is scheduled to expire by 2009, but could be made permanent during the second Bush administration.

\subsection{Ex-Dividend Day Returns and Taxes}

The profit from selling at the end of cum-day (just preceding the ex-day) should equal the profit from selling at the beginning of the ex-day in order to eliminate arbitrage opportunities. In a world without taxes, this would mean that the drop in share price around the ex-day should equal the dividend per share. However, as first recognized by Elton and Gruber (1970), dividend and capital gains taxation can prevent this equality from holding. Ignoring overnight interest, the no-arbitrage condition with taxes is:

$$
P_{B}-t_{g}\left(P_{B}-P_{0}\right)=P_{A}-t_{g}\left(P_{A}-P_{0}\right)+D\left(1-t_{d}\right)
$$

where

\footnotetext{
${ }^{5}$ More precisely, taxpayers in the bottom two income tax brackets (facing a regular marginal tax rate of 10 or 15 percent) face a new dividend tax rate of 5 percent, while taxpayers in the top four brackets (facing marginal tax rates of $25,28,33$, or 35 percent) face a new dividend tax rate of 15 percent. Taxpayers on the Alternative Minimum Tax schedule (flat rate of 28 percent) benefit from the reduced 15 percent tax rate on their dividend income as well. Individual dividend income earned through tax-favored accounts such as $401(\mathrm{k}) \mathrm{s}$ and dividend income earned by government agencies, nonprofit organizations, and corporations are not affected by the tax change.

${ }^{6}$ Auerbach and Hassett [this volume] discuss the timing of the tax reform legislative process in detail. They find that the reduction of dividend taxation was not discussed seriously before the end of December 2002. It was not mentioned in the Bush 2000 campaign platform either, suggesting that there was no anticipation that such a tax change would take place before the very end of 2002 .
} 
$P_{A}$ is the stock price cum-dividend (just before the ex-dividend day starts),

$P_{B}$ is the expected stock price on the ex-day,

$P_{0}$ is the stock price at initial purchase (tax base),

$D$ is dividend amount per share,

$t_{g}$ is the tax rate on realized capital gains,

$t_{d}$ is the tax rate on dividend income.

Rearranging equation (1), we obtain:

$$
\frac{P_{A}-P_{B}}{D}=\frac{1-t_{d}}{1-t_{g}} \equiv \rho
$$

The left-hand-side of this expression is called the ex-day premium. The right-hand-side variable captures the differential tax treatment of dividends versus realized capital gains and is called the ex-day tax preference ratio, which we denote by $\rho$. Without taxes, the premium is expected to be equal to one: the price falls by the exact amount of the dividend premium. ${ }^{7}$

Figure 1 depicts the case of the large $\$ 3$ special dividend payment from Microsoft. This special payment represented about $10 \%$ of the share price value and hence was large relative to day to day variation in stock prices, making the ex-dividend day drop in price clearly visible on the graph. ${ }^{8}$ The drop in price is $\$ 2.58$, generating a premium of 0.86 . This value is fairly close to the value of 1 predicted by (2) in 2004, when the statutory rates for dividends and long-term realized capital gains were equal. ${ }^{9}$

There is a controversial debate in the literature about whether taxes actually affect the premium as in (2). Traditionally, the individual tax rate of dividend income has been substantially higher than the individual tax rate on (long-term) realized capital gains. Elton and Gruber (1970) estimated premia for US corporations in 1966-7 lower than one and argued that the differential tax could explain those results. Consistent with this claim, Barclay (1987) showed that the premium was not significantly different from one in the United States before the individual income tax was introduced in the United States in 1913 but was significantly

\footnotetext{
${ }^{7}$ This simple derivation hides complexities which can arise if the marginal investor considers buying (instead of selling) just before or after the ex-day. If the resulting capital loss incurred at the ex-day can be offset against capital gains, the same premium formula applies. The premium formula would be different, however, if the capital loss could not be offset or was offset against ordinary income.

${ }^{8}$ Most dividend payments are small relative to day to day price variation making the drop in price impossible to detect looking at a single firm price series.

${ }^{9}$ More precisely, the rates were $15 \%$ for taxable individuals who had owned the stock at least one year. Hence we would observe a premium equal to one if only taxable individuals had been trading.
} 
below one in 1962-5 when the tax differential was large. However, Michaely (1991) found no significant increase in the premium around the Tax Reform Act of 1986, which eliminated the favorable tax treatment of realized capital gains and thereby raised $\rho$ sharply. ${ }^{10}$

One limitation of (2), which could explain why it fails to explain observe premia well, is that it assumes that all agents face the same tax rates. In practice, however, there is substantial heterogeneity in the tax preferences of shareholders, as pointed out by Michaely (1991). Table 1 reports the overall ex-day tax preference ratio weighted by share of stock ownership in the US economy. The estimates are based on Poterba (2004) as well as unpublished appendix series kindly made available to us by James Poterba. ${ }^{11}$ Long-term individual owners in high income tax brackets have typically faced a tax preference less than one. The tax ratio was equal to one briefly after TRA 1986 and again after the 2003 dividend tax cut. All non-taxable institutions such as pension funds and individual pension accounts (IRAs and 401(k)s), non profit organizations, government agencies, as well as individuals holding stock for the shortterm have faced a tax ratio equal to 1 . In contrast, corporations have typically faced a ratio above one as only a fraction of dividend income received by a corporation is taxable and realized capital gains made by a corporation are fully taxable at normal rates.

A number of studies (see e.g., Auerbach, 1983 in the public economics literature or more recently Michaely and Villa, 1995 in the finance literature) have developed models with heterogeneous risk averse investors. Those studies show that equation (2) can be generalized. In that case, the premium equals the average of the tax ratios weighted by risk tolerance. Kalay (1982), and Eades, Hess, and Kim (1984) point out that discreteness in prices may cause a bias in measuring the ex-day price drop relative to the dividend (until recently, the minimum tick size was one-eighth in the U.S.). This bias may cause the average price drop to be less than the dividend amount. In principle, these other effects should not eliminate the tax effects, but rather describe other channels that can potentially affect ex-day premia.

\footnotetext{
${ }^{10}$ Similarly, Lakonishok and Vermaelen (1983) did not find that the premium moved in the expected direction following a tax change in Canada. Poterba and Summers (1984), however, did find evidence consistent with the predicted tax effect in the case of the United Kingdom.

${ }^{11}$ Poterba (2004) includes only $25 \%$ of the statutory realized capital gains tax rate because he wants to estimate the effective burden on accrued capital gains. For the ex-dividend date tax ratio, however, the statutory tax rate on realized capital gains is the relevant one and this is what we use for our analysis of ex-day premiums.
} 


\subsection{Dividend Increase Announcement-Day Returns and Taxes}

Corporations distribute profits to shareholders in two main forms: dividends and share repurchases. In a world without taxes and with perfect information, share repurchases and dividends are equivalent. However, the market appears to treat these two forms of payout very differently in practice. Reducing or terminating regular dividend payments carry a very negative signal and are heavily penalized by investors. In contrast, share repurchases (or one time special dividend payments) are not seen as a commitment to continue paying in the future, and accordingly announcements of repurchases generate far lower excess returns than announcements of dividends.

One reason that these two forms of payout may not be equivalent in the current equilibrium is that their tax treatment differs. Under U.S. tax law, realized capital gains have traditionally been taxed more lightly than dividend income, making share repurchases a more tax efficient way of distributing profits. The relative tax disadvantage of dividends relative to capital gains (repurchases) can be measured using the tax preference parameter constructed by Poterba (2004). This tax ratio is estimated as the average across all types of shareholders in the US economy and weighted by ownership of $\left(1-t_{d}\right) /\left(1-t_{a c}\right)$ where $t_{d}$ is the marginal tax rate on dividend income and $t_{a c}$ is the effective tax rate on capital gains. This effective rate measures the real tax rate on capital gains on an accrual equivalent basis. It should not be confused with the actual rate on realized capital gains that we used above. Because of tax deferral (or no tax at all if capital gains are not realized before death), the effective rate is much lower than the statutory rate. We denote this deferral-adjusted tax preference parameter by $\theta$ and report its time series in Table 2.

Share repurchases became more common following a SEC ruling in 1982 which clarified the rules under which corporations could legally make share repurchases without being subject to dividend taxation (Grullon and Michaely, 2002). Despite the rise in share repurchases, dividends remain an important conduit for distributing profits. The reason why dividends have not been entirely replaced by share repurchases has been termed the "dividend puzzle." The literature has proposed two main theories to resolve this puzzle: the signalling theory and the agency theory. Bernheim and Wantz (1995) pointed out that the effect of taxes on announcement premia could be used to test theories of dividend payment. Allen and Michaely 
(2003) provide an extensive survey of this literature which we summarize briefly below.

Under the signalling theory (see Bernheim and Wantz for a clear exposition), dividends serve as a costly signal of a firm's profits prospects. Firms effectively burn money in the form of dividend payments (as they incur a higher tax burden than if they repurchased shares) to signal to the market their profitability. Higher profits firms are able to burn more money and therefore in equilibrium dividends indeed signal profitability. If the relative tax of dividends versus realized capital gains increases, it is more costly to pay dividends. Therefore, the market reaction to dividend increases should be stronger when $\theta$ is low.

Under the agency theory (see e.g., Jensen and Meckling, 1976), there is a conflict of interest between management and stockholders. In that context, dividends can be seen as a device to prevent managers from spending the earnings of the corporation in inefficient projects (such as pet projects or empire building). Increasing the dividend tax rate relative to realized capital gains increases the costs of dividends without affecting benefits. Therefore, the market should react less favorably to dividend increases when $\theta$ is low. Thus the signalling theory and the agency theory generate opposite predictions on the effect of changing the relative tax of dividends and capital gains on the excess stock price return around announcement dates of dividend increases.

Bernheim and Wantz (1995), using US data from 1962 to 1988, show that the market premium for increasing or initiating dividends is larger when the relative tax rate on dividends is higher. This result supports the signalling theory. However, Bernhardt, Robertson, and Farrow (1994) using Canadian data and Grullon and Michaely (2001) using US data around the Tax Reform Act of 1986 investigated the same issue and found that higher tax rates were actually associated with lower dividend announcement premiums, supporting the agency theory. Much of the dispute in both the ex-date and announcement date literatures stems from the lack of sharp, credible variation in tax rates. In this paper we investigate the broader time series and examine in detail the 2003 dividend tax cut episode to assess whether robust results on the effects of taxes can be obtained. 


\section{Data and Methods}

We use data from the CRSP, which reports all dividend events (announcements, ex-dividend date, dividends per share) as well as price series at the daily level since 1962 for all companies listed on the major U.S. exchanges: NYSE, AMEX, and NASDAQ. ${ }^{12}$ Specifically, we take all ordinary dividends paid in U.S. dollars (CRSP distribution codes beginning with 12) on ordinary common shares (CRSP share codes 10, 11, and 12) trading on either the NYSE, AMEX, or NASDAQ (CRSP exchange codes 1, 2, and 3). We focus our analysis exclusively on taxable dividend events (CRSP distribution codes ending in 2) and discard all non taxable events. $^{13}$

For our ex-dividend day analysis, we consider all events whose ex-date is between 1963 and 2004 and for which the stock was traded on the ex-dividend day and the business day preceding the ex-dividend day. We also discard events for which CRSP does not report actual closing prices for either the ex-day or cum-day. As noted by Elton and Gruber (1970), it is important to discard events during which there was no trading of the stock because in those cases, regulations require to adjust the stock price mechanically downward by the full value of the nominal dividend. This mechanical adjustment would produce a premium equal to one. In addition, we discard a very small number of events with dividend yields of less than 0.1 percent (roughly $1 \%$ of the total sample) or ex-day price changes of more than 80 percent (7 events). The annual number of events in the sample is reported on Table 1, col. (2). Annual times series are always reported according to payment date, which is the relevant date for tax purposes.

For each of the 256,360 ex-day events in our sample, we compute the ex-day premium as the beta-adjusted difference between the cum-day closing price and the ex-day closing price divided by the nominal dividend payment per share. Specifically, the premium for firm $i$ is:

$$
\operatorname{Prem}_{i}=\frac{P_{i}^{c u m}-P_{i}^{e x} /\left(1+\hat{\alpha}_{i}+\hat{\beta}_{i} r^{m}\right)}{D_{i}}
$$

where $r^{m}$ is the value-weighted return on the CRSP NYSE/AMEX/NASDAQ market index, and $\hat{\alpha}_{i}$ and $\hat{\beta}_{i}$ are estimated using a firm level regression of the firm return on the market

\footnotetext{
${ }^{12}$ The NASDAQ was introduced in 1972.

${ }^{13}$ Non-taxable dividends are very rare, making it difficult to use such dividends as a control. See Eades, Hess and Kim (1984) for such an attempt.
} 
return and a constant over a 91 day window centered on the ex-dividend date. ${ }^{14}$

Columns (3) to (5) on Table 1 report various annual statistics for the premia: the median, the weighted (by dividend yield) average, and the trimmed unweighted average (events with dividend yields less than 0.45 percent, roughly $25 \%$ of events, are discarded). ${ }^{15}$

For our announcement analysis, we consider all regular dividend events (CRSP distribution codes $1222,1232,1242$, and 1252) which were higher (in nominal terms) than the previous regular dividend payment of the same firm. We also include all dividend initiations, defined as a firm paying a regular dividend payment for the first time over the last 6 quarters. A firm making its first dividend payment will only be classified as an initiator if the firm existed in the CRSP database for at least 6 quarters prior to announcing the dividend. We exclude a dividend event if its periodicity (annual, semi-annual, or quarterly) is different from the previous payment.Similar to the ex-day analysis, we discard a very small number of events with change in dividend yield of less than 0.001 percent (less than $1 \%$ of the total sample) or three-day excess returns of more than 80 percent in absolute value (1 event). Col. (3) in Table 2 reports the annual number of such dividend increase events. ${ }^{16}$

For each of the 38,951 dividend increase announcements in our sample, we compute the announcement premium as the beta adjusted excess return between the closing price on the day after announcement and the closing price 2 days before announcement divided by the nominal change in the dividend payment per share (adjusted for splits). The beta adjustment is estimated using a firm level regression of the firm return on the market return and a constant over the 91 days centered on the announcement date. Presumably, a annual dividend increase of $x$ cents should be equivalent to a quarterly dividend increase of $x / 4$ cents. Therefore, in order to normalize our estimate of $\Delta P / \Delta D$ to quarterly dividend increases (by far the most common form of regular dividend payments), we divide the premium by 4 for annual payments, and by 2 for semi-annual payments.

Columns (4) to (6) on Table 2 report various annual statistics for the dividend announce-

\footnotetext{
${ }^{14}$ Our premium equation considers $P^{c u m}$ as the base price and deflates $P^{e x}$ by the market adjusted return. Alternatively, we could have considered $P^{e x}$ as the base price and inflate $P^{\text {cum }}$ by the market adjusted return. As the time window between the cum and ex-days is very short, these two definitions produce extremely similar results.

${ }^{15}$ It is necessary to trim an the un-weighted average because for that series, very small dividend payments will drive the results and generate substantial noise in the series.

${ }^{16}$ Again, announcements are classified in the time series according to payment date, which is the relevant date for tax purposes.
} 
ment ratio: the median, the weighted (by the ratio of the change in the nominal dividend per share to the closing share price 2 days before announcement) average, trimmed unweighted averages (in that case dividend events in which the change in the dividend per share divided by the pre-announcement share price is less than 0.045 percent, roughly the bottom $25 \%$, are discarded).

For our regression analysis, we merge the CRSP data with the annual Compustat database, losing some firms because not all firms listed in CRSP are covered by Compustat.

\section{Empirical Results for Ex-Dividend Days}

\subsection{The 2003 tax cut experiment}

We start by analyzing the 2003 dividend tax cut. Table 3 shows that the 2003 tax cut increased the ex-day tax ratio $\rho$ significantly from 0.95 (in 2002) to 1.02 (in 2003 and after). Because the 2003 tax change was enacted only in late May 2003, there was considerable uncertainty in the first half of 2003 about the tax rates for dividends and capital gains that would apply then. Therefore, we compare 2002 and 2004, years for which the tax rates were unambiguously defined throughout.

Table 3a reports the trimmed mean, median, and dividend weighted mean of the ex-day premium $(\Delta P / D)$ in the pre-reform (2002) and post-reform (2004) periods, as well as the change in these three measures between the two periods. ${ }^{17}$ All three measures increase from 2002 to 2004, consistent with the tax theory described above. All the increases are statistically significant at the $5 \%$ level. Those standard errors are computed assuming iid errors and in particular no year specific aggregate shocks. ${ }^{18}$ However, the magnitudes of the changes are generally far larger than the change in the premium of 0.07 , contradicting the 1-1 response predicted by the simple Elton-Gruber framework described above. ${ }^{19}$ To assess the robustness of these findings from a broader perspective, we now analyze the full 1962-2004 period and examine whether the behavior of ex-day premia the 2003 tax cut is unusual.

\footnotetext{
${ }^{17}$ All those premia are regression adjusted for market returns as described in the data section.

${ }^{18}$ Obviously, with only two years of data, it is impossible to estimate standard errors if year specific aggregate shocks are not assumed away.

${ }^{19}$ In addition, the premium measures are lower than the tax ration $\rho$ in each period.
} 


\subsection{Time series perspective}

Figure 2 displays the time series of the trimmed mean, median, and dividend weighted mean of the ex-day premium along with the average tax preference ratio $\rho$. All of these series are taken directly from Table 1 . The three measures of the ex-day premia are relatively close in levels and highly correlated. The mean/median premium is almost always below 1 , consistent with the original Elton-Gruber prediction. However, there is substantial time variation in the premium: It declines from 1 to 0.7 in the 1960s, then goes back up to 1 in the 1970s. It then drops again in the 1980s to 0.7 . Since 1990, the ratios have generally remained below 0.8 , but year to year variations are even larger. Most notably, the three premium measures dropped dramatically from about 0.7 in the mid 1990s to less than 0.4 from 1999 to 2000. The premia increased consistently from their low in 2000 and quickly returned to 0.8 in 2004 .

\section{Parametric Regression Estimates}

To assess the relationship between taxes and the premium following methods used in the existing literature, we run dividend-yield weighted regressions of the following form:

$$
\frac{\Delta P_{i t}}{D_{i t}}=\alpha+\delta \rho+\gamma X_{i t}+\varepsilon_{i t}
$$

where $X$ is a set of covariates. Specifications 1-3 of Table 4 run the regression specification above restricting the sample to particular years around tax events. The covariate set in these and all subsequent regressions reported in the Tables is each firm's lagged (prior year) cash, assets, liabilities, earnings, and investment, and the level and square of the 10 year U.S. treasury yield. The main results are very similar when the covariates are dropped or the set of covariates is changed. The table shows that results are very fragile when one examines specific "natural experiments" using windows around sharp changes in tax rates. Specification 1 examines the period from 1980-1985. The premium fell significantly from 1980-1985 while $\rho$ increased, yielding a negative and highly significant estimate of $\delta$ in this specification. But as Michaely (1991) found, specification 2 shows that the premium in 1985-89 is relatively stable while $\rho$ increases sharply because of TRA86 (note that the levels we estimate are different from Michaely mainly because of differences in sample), yielding an estimate of zero. Finally, as discussed above, the ex-day premium increases sharply (and significantly) from 2002 to 2004, coincident with the 2003 tax cut, which increased $\rho$ by 0.07 . This yields a positive estimate of $\delta$ (specification 3). Hence, depending on which short-run tax episode one picks, one can 
obtain a negative, zero, or positive association between $\rho$ and the ex-day premium.

Moreover, "placebo tests" suggest violations of the identification assumptions that there are no other short-run trends. For instance, the ex-day premium also rose at a significant rate from 1999 to 2002, a time when $\rho$ was virtually flat. This suggests that it would not be credible to attribute the increase in the premium around the 2003 dividend tax cut solely to the tax change. Hence, our initial results using the 2003 tax cut are not robust when examined in the context of the longer time series. The changes around the 2003 reform, though large and significant in short-window regressions, are hardly unusual relative to other non-tax related time series fluctuations.

\section{Power Analysis}

The fragility of these estimates arises fundamentally from the very large aggregate volatility in the excess returns. This point can be seen with a simple power analysis. First, note that the standard deviation of the trimmed mean premium in the time series is $\sigma=0.13$. Now suppose there is a one-time, discrete change in $\rho$ of 10 percentage points, a value larger than any single tax change in our sample. Assume that the true mean change in $\Delta P / D$ caused by this tax change is 10 percentage points (consistent with the Elton-Gruber model). To see how much data is needed to detect this effect, note that the standard error interval for the mean premium over $n$ years is $\frac{\sigma}{\sqrt{n}}=\frac{0.13}{\sqrt{n}}$. If observations are independent across years, the standard error for the change in the premium with $n$ years each of pre-reform and post-reform data is $s e=\sqrt{2} \frac{\sigma}{\sqrt{n}}$. Note that increasing the sample size within any given year is unlikely to reduce $\sigma$ drastically because idiosyncratic firm-level shocks are essentially washed out in the large samples used for each year (see Table 1). Therefore, the primary way to increase the precision of the estimates is to increase the number of years in the data.

To detect a change in $\Delta P / D$ of 0.1 at conventional significance levels, we would need an $s e=0.05$, which would require $n=14$ years of pre-reform data and 14 years of postreform data! Even if there were a sharp change in $\rho$ and $\Delta P / D$ of 20 percentage points (which equals the change in $\rho$ from 1964-2004), we would need 8 years of data (4 pre and 4 post) to pick up the effect. Given the volatility in the data, one needs both a very large tax change and also a long pre-reform and post-reform period to have a chance of detecting even large tax effects. ${ }^{20}$ Of course, these conditions guarantee precision but not necessarily

\footnotetext{
${ }^{20}$ The pattern of the time series on Figure 2 suggests that the year to year fluctuations are actually positively
} 
consistency. Consistency of estimates using this identification strategy requires that there are no unobservable contemporaneous trends that may make the average premia in the pre and post periods differ. Unfortunately, this assumption is quite tenuous when one is comparing premia over long horizons, especially given the apparently non-tax related aggregate fluctuations and short-term trends (such as the one from 2000-2004) evident in the data. The power analysis therefore indicates that the ability to make credible inferences about tax effects is quite limited using raw data on ex-dividend returns.

\section{Attempted Solutions}

One way to try to increase power is to control for other factors that may be contributing to the aggregate volatility. Intuitively, if one can pin down the factors that are driving the fluctuations, the residuals after controlling for these factors will be much smoother, permitting more reliable inferences about tax effects. To investigate this approach, we run a dividendweighted regression of the ex-day premium on year dummies, the ten-year nominal interest rate, and a set of observable variables from Compustat data: cash, assets, liabilities, earnings, and investment. Figure 3 plots the coefficients on the year dummies in this regression, which correspond to the ex-day premia adjusting for controls, alongside the raw means shown in Figure 2. The main lesson is that adding controls hardly affects the pattern of the ex-dividend day premiums, indicating that the main observables are poor predictors of the aggregate fluctuations. In addition, the lack of monotonicity in the excess premiums suggests that it is impossible to explain the evolution of the premium with variables such as reductions in trading transaction costs, the elimination of discrete pricing rules, or the development of tax-sophisticated arbitrage techniques.

Given our inability to smooth cross-year fluctuations, we now turn to a slightly different test that exploits the within-year variation in the size of dividend payments. Specifically, we examine whether larger dividend payments are associated with larger ex-day returns particularly in years with high $\rho$. The following dividend-weighted regression is estimated for each year $t$ :

$$
r_{i t}=\alpha_{t}+\delta_{t} \frac{D_{i t}}{P_{i t}}+\gamma X_{i t}+\varepsilon_{t}
$$

where $r_{i t}$ denotes the ex-day excess return $(\Delta P / P), \frac{D_{i t}}{P_{i t}}$ is the dividend yield, and $\delta_{t}$ is the slope serially correlated. In that situation, our power calculation is too optimistic and even more years of data would be required to detect an effect. 
coefficient in year $t$. We then investigate the link between the estimated $\left\{\delta_{t}\right\}$ time series and the time series of $\rho$ graphically (to permit a semi-parametric analysis as above). A tax effect would imply that $\delta_{t}$ should be larger when $\rho_{t}$ is large because larger dividend payments should generate especially large (negative) excess returns on the ex-date if the dividend payment is very valuable to investors, i.e. if dividend taxation is low and $\rho_{t}$ is high. Figure 4 shows the evolution of $\delta_{t}$ first from a specification without additional controls and then from a specification that includes the standard control set described above. The $\delta_{t}$ coefficients are consistently positive, confirming that larger dividend payments generate larger ex-day price reductions. However, the $\delta_{t}$ coefficients also vary tremendously from year to year, suggesting that this approach will not help in our ultimate goal of raising power so that we can detect tax effects.

Panel B of Table 4 examines whether regression analysis can uncover significant effects in this within-year test. This panel reports estimates of the following specification:

$$
r_{i t}=\alpha+\delta_{0} \rho+\delta_{1} \frac{D_{i t}}{P_{i t}}+\delta_{2} \rho_{t} \frac{D_{i t}}{P_{i t}}+\gamma X_{i t}+\varepsilon_{i t}
$$

The key coefficient of interest for this test is the interaction term, $\delta_{2}$. The same five specifications as in Panel A of Table 4 are repeated and results are insignificant and of varied signs in all short-window regressions. Given the lack of power suggested by Figure 4, it should not be surprising that the parametric (linear) regression counterparts to this graph yield little information.

Finally, we explore whether the pattern of premia becomes smoother when one constructs the sample of firms differently to control for potential changes in the sample over time. First, we limit the sample to large firms (ranked by market capitalization), for which trading costs are lower and whose dividends are perhaps more visible to traders. As show in Figure 5, Panel A, the resulting series is even noisier than that depicted on Figure 2, and is not any more closely related to the tax parameter $\rho$. Second, to control for potential noise from entry and exit effects, we also estimate average premia for a stable set of firms over time (those alive since 1990). This series also remains as noisy as the original one (Figure 5, Panel B).

\section{Summary.}

A graphical (semi-parametric) analysis of the full time series of ex-day premia helps reconcile the various ex-day tax effects estimated using regressions that make parametric assump- 
tions (e.g., linearity) in the literature. Each of the estimates are significant within the specific event window analyzed in the study, but are not robust to a broader examination that takes into account the tremendous aggregate volatility in the premia. This point applies to the 2003 tax cut analyzed above as well. The lack of a robust relationship between taxes and the ex-day premium in the data should not be interpreted as evidence that taxes are not relevant. Rather, it reveals that one cannot place a reasonable confidence interval on the size of the tax effect with the methods employed in the existing literature.

\section{Empirical Results for Dividend Announcements}

We now investigate the relationship between taxes and excess returns on announcement days. As the methods and basic conclusions are very similar to those in the ex-day analysis, the discussion below is much briefer.

\subsection{The 2003 tax cut experiment}

Table 3, Panel B shows that the 2003 tax cut increased the deferred-capital taxation adjusted tax preference ratio $\theta$ from 0.86 (in 2002) to 0.93 (in 2003 and after). As above, we compare 2002 and 2004, years for which the tax rates were unambiguously defined throughout. Table 3 , Panel B, reports the trimmed mean, median, and $\Delta D$-weighted mean of the premium $\frac{\Delta P}{\Delta D}$ associated with a dividend increase of $\Delta D$. All three of these measures decrease from 2002 to 2004. The first decline is statistically significant (at the $5 \%$ level) while the last two are only marginally significant. These results are consistent with Bernheim and Wantz (1994). They support the signalling theory of dividend payments while rejecting the agency theory. To assess the robustness of this result, we now analyze this event in the context of the full 1963-2004 sample period.

\subsection{Time series perspective}

Figure 6 shows the times series of the trimmed mean, median, and weighted mean premium. It also shows the average tax preference ratio $\theta$ taken from Poterba (2004) on a separate (right hand side) scale. All of these series are taken directly from Table 2. The three measures of the premia are reasonably similar for most years. They are consistently positive, confirming the well known result that dividend increase announcements generate a positive market reaction 
on average. There is a clear decline in the announcement premiums over time, although there is substantial year to year variation as well. The median and weighted mean series are smoother than the trimmed mean series. This is to be expected given that the signal to noise ratio in small $\Delta D$ announcements is presumably much lower.

\section{Parametric Regression Estimates.}

To investigate the effect of taxes on the announcement premium using traditional linear regression methods, we fit models of the following form:

$$
\frac{\Delta P_{i t}}{\Delta D_{i t}}=\alpha+\delta \theta_{t}+\gamma X_{i t}+\varepsilon_{i t}
$$

Table 5, Panel A reports a set of estimates of this equation, with a control set $X$ identical to that used in Table 4 . The regressions are weighted by $\Delta D / P$. Examination of the key taxreform episodes using "natural experiment" methods is equally problematic here. As shown in columns (1) to (3) of Table 5, the three tax episodes each yield very different estimates with very large standard errors. Placebo tests also suggest problems. The premium is indeed lower in 2004 than in 2002 after the tax ratio increases. But this negative relation is not robust, for example, to choosing year 2000 instead of year 2002 as the pre-reform comparison. Hence, as with the ex-dividend case, we conclude that our initial results using the 2003 reform are far from compelling when viewed from the longer time-series perspective.

Power Analysis. The fragility of these estimates can again be traced to the aggregate volatility in the excess returns around announcement days. An analysis identical to that for the ex-dividend days suggests that detecting even a very large change in the premium of $\Delta P / \Delta D=3$ (a $50 \%$ increase relative to the mean $\Delta P / \Delta D$ ) would require 8 years of pre-reform and 8 years of post-reform data given the observed degree of aggregate volatility. Examining such a long horizon raises the same identification problem related to other trends that were discussed in the context of the ex-day analysis. Hence, there the power to make inferences about announcement premia appears equally limited.

Attempted Solutions. We consider the same three approaches to resolving this aggregate noise problem as we did in the ex-dividend case. First, we investigate whether controls can smooth aggregate fluctuations. We run a $\Delta D$-weighted regression of the announcement premium $\Delta P / \Delta D$ on year dummies, the ten-year interest rate, and the following set of observables from Compustat: cash, assets, liabilities, earnings, and investment. Figure 7 plots the coeffi- 
cients on the year dummies in this regression alongside the raw means shown in Figure 2. It is clear that the addition of controls does little to mitigate the aggregate fluctuations.

Second, we examine whether larger dividend payments are associated with larger announcement returns particularly in years with high or low $\theta_{t}$. Specifically, we run the following $\Delta D / P$-weighted regression:

$$
r_{i t}=\alpha_{t}+\delta_{t} \frac{\Delta D_{i t}}{P_{i t}}+\gamma X_{i t}+\varepsilon_{i t}
$$

where $r_{i t}$ denotes the ex-day excess return $(\Delta P / P), \frac{D_{i t}}{P_{i t}}$ is the dividend yield, and $\delta_{t}$ is the slope coefficient in year $t$. We then investigate the link between the estimated $\left\{\delta_{t}\right\}$ time series and the time series of $\theta$ graphically as in the ex-day analysis. Figure 8 shows the evolution of $\delta_{t}$ first from a specification withou additional controls and then from a specification that includes the standard controls. The $\delta_{t}$ coefficients are consistently positive, confirming that larger dividend payments generate larger announcement premia. However, the $\delta_{t}$ coefficients also vary tremendously from year to year, suggesting that power is not any greater for this type of test.

Panel B of Table 5 examines whether regression analysis can uncover significant effects in this within-year test. This panel reports estimates of the following specification:

$$
r_{i t}=\alpha+\delta_{0} \theta+\delta_{1} \frac{\Delta D_{i t}}{P_{i t}}+\delta_{2} \theta \frac{\Delta D_{i t}}{P_{i t}}+\gamma X_{i t}+\varepsilon_{i t}
$$

Note that this is precisely the "bang-for-the-buck" specification implemented by Bernheim and Wantz (1994). The key coefficient of interest for this test is the interaction term, $\delta_{2}$. The results are insignificant and of varied signs in the short-window regressions that are perhaps most credible from an identification perspective. Unfortunately, it appears that little is gained from examining the within-year variation in the size of dividend increase announcements because of the instability of the relationship over time.

Finally, we explore whether changes in the sample construction affect the smoothness of the series. The results (not reported) suggest little difference between constant-firm samples or large-firm samples and the full sample we initially examined.

Summary. Our conclusions for the announcement day tax effects mirror those for the ex-dividend day analysis. Both time-series and event-study methods yield very unstable results with wide confidence intervals for the effects of taxation on announcement premia. 
The problem again is aggregate volatility and the resulting lack of power. Some obvious attempts to smooth the series fail. The source of the aggregate fluctuations must therefore be understood before real progress can be made on estimating the tax effects.

\section{Conclusion}

The original goal of our analysis was to use the sharp change in the tax treatment of dividend income in 2003 to examine the effect of taxes on dividend announcement and ex-day premia. The 2003 tax cut is unique in its size and relatively unanticipated nature, and thereby provides one of the best "natural experiments" to study these issues. Unfortunately, we found that few robust inferences can be drawn about the effects of taxation on excess returns even using this large experiment. Analysis of the full time series of excess returns around announcement and ex-dates reveals a high degree of aggregate volatility that cannot be smoothed using covariates such as assets or profit rates or by changes in sample construction. Our main conclusions are therefore methodological:

[1] Existing methods, which generally involve parametric (often linear) regressions and/or examination of short windows around tax changes, yield unstable and sometimes misleading results. Looking at the time series from 1962-2004, we found that the results are extremely sensitive to the window of analysis and the specification used. The contradictory estimates of prior studies can be explained by the particular event windows and specifications that were chosen in each study.

[2] Obtaining credible estimates of tax effects requires the use of a long time series of data. The objective is not to do a time-series analysis, but rather to check whether the changes in the series around a tax experiment are unusual relative to historical non-tax-related aggregate fluctuations. Semi-parametric tests showing that changes around a particular reform are very different from other fluctuations could give the most robust evidence of tax effects.

[3] In the context of ex-day and announcement premia for dividends, the aggregate series is so volatile that even large tax changes yield very wide confidence intervals on the tax effects. The statistical power to pick up even large tax effects is limited. Credible estimates of the effects of dividend taxation on equity returns are likely to remain elusive until we have better models that explain the non tax-driven fluctuations in the aggregate time series. We view the 
search for such models as the most promising direction for future research in this area.

Another promising avenue for more research would be to look directly at trading data (as opposed to only prices, as done here) to uncover the mechanisms of tax arbitrage around the ex-day dates. Indeed, several studies (see Allen and Michaely, 2003 for a survey) have started to explore trading volume data around ex-dividend dates. A natural extension of this work would be to explore whether trading volume, and the nature of traders around ex-days, correlates with the size of premium over time. 


\section{References}

Allen, Franklin and Roni Michaely, 2003, "Payout Policy," in Constantinides, George, Milton Harris and Rene Stulz eds. Handbook of the Economics of Finance (Amsterdam: NorthHolland)

Auerbach, Alan, 1983, "Stockholder tax rates and firm attributes,", Journal of Public Economics 21(2), 107-127.

Auerbach, Alan, 2003, "Taxation and Corporate Financial Policy," in Auerbach, Alan and Martin Feldstein eds. Handbook of Public Economics, Volume 3, (Amsterdam: North-Holland)

Auerbach, Alan and Kevin Hassett, 2005, "The Corporate Response to the 2003 Act: Did the Old View or the New View Win Out?," this volume.

Barclay, Michael (1987), "Dividends, Taxes, and Common Stock Prices: The Ex-Dividend Day Behavior of Common Stock Prices before the Income Tax", Journal of Financial Economics 14, 31-44.

Bernhardt, Dan, J. Fiona Robertson and Ray Farrow, 1994, "Testing Dividend Signaling Models," Working Paper, Queen's University.

Bernheim, Douglas and Adam Wantz (1995), "A Tax-Based Test of the Dividend Signalling Hypothesis", American Economic Review 85(3), 532-551.

Blouin, Jennifer, Jana Raedy, and Douglas Shackelford (2004), "The Initial Impact of the 2003 Reduction in the Dividend Tax Rate", University of North-Carolina, Chapel Hill, Working Paper.

Chetty, Raj and Emmanuel Saez (2004), "Dividend Taxes and Corporate Behavior: Evidence from the 2003 Dividend Tax Cut", forthcoming Quarterly Journal of Economics, August 2005.

DeAngelo, Harry, Linda DeAngelo, and Doug Skinner, 2000, "Special Dividends and the Evolution of Dividend Signaling," Journal of Financial Economics, pp. 309-354.

Eades, Ken, Pat Hess and Han E. Kim, 1984, "On Interpreting Security Returns During the Ex-dividend Period," Journal of Financial Economics, 13, 3-34.

Elton, Edwin and Martin Gruber (1970), "Marginal Stockholders Tax Rates and the Clientele Effect," Review of Economics and Statistics 52, 68-74.

Grullon, Gustavo and Roni Michaely, 2001, "Asymmetric information, agency conflicts and the impact of taxation on the market reaction to dividend changes," Working paper, Cornell University, Ithaca NY.

Grullon, Gustavo and Roni Michaely, (2002) "Dividends, Share Repurchases, and the Substitution Hypothesis", Journal of Finance, 57(4), 1649-1684.

Jensen, Michael C. and William H. Meckling (1976), "Theory of the Firm: Managerial Behavior, Agency Costs and Ownership Structure," Journal of Financial Economics, 3(4), 305-360.

Kalay, Avner, 1982, "The Ex-dividend Day Behavior of Stock Prices: A Re-examination of the Clientele Effect,' Journal of Finance, 37, 1059-1070.

Lakonishok, J. and T. Vermaelen, (1983), "Tax reform and ex-dividend day behavior" Journal of Finance 38(4), 1157-1179. 
Michaely, Roni (1991) "Ex-Dividend Day Stock Price Behavior: The Case of the 1986 Tax Reform Act", Journal of Finance, 46(3), 845-859.

Michaely, Roni and Jean-Luc Vila (1995), "Investors' Heterogeneity, Prices and Volume Around the Ex-Dividend Day," Journal of Financial and Quantitative Analysis 30, 171-198.

Perez-Gonzalez, Francisco, 2003, "Large shareholders and dividends: Evidence from U.S. tax reforms", Working paper, Columbia University.

Poterba, James, 2004, "Corporate Payout Policy", American Economic Review, 94(2), 171175 .

Poterba, James and Lawrence Summers, 1984 "New Evidence that Taxes Affect the Valuation of Dividends", Journal of Finance 39, 1397-1415.

Poterba, James and Lawrence Summers, 1985 "The Economic Effects of Dividend Taxation", in E. Altman and M. Subrahmanyam, eds., Recent Advances in Corporation Finance (Homewood, IL: Dow Jones-Irwin), 227-284. 


\section{Figure 1}

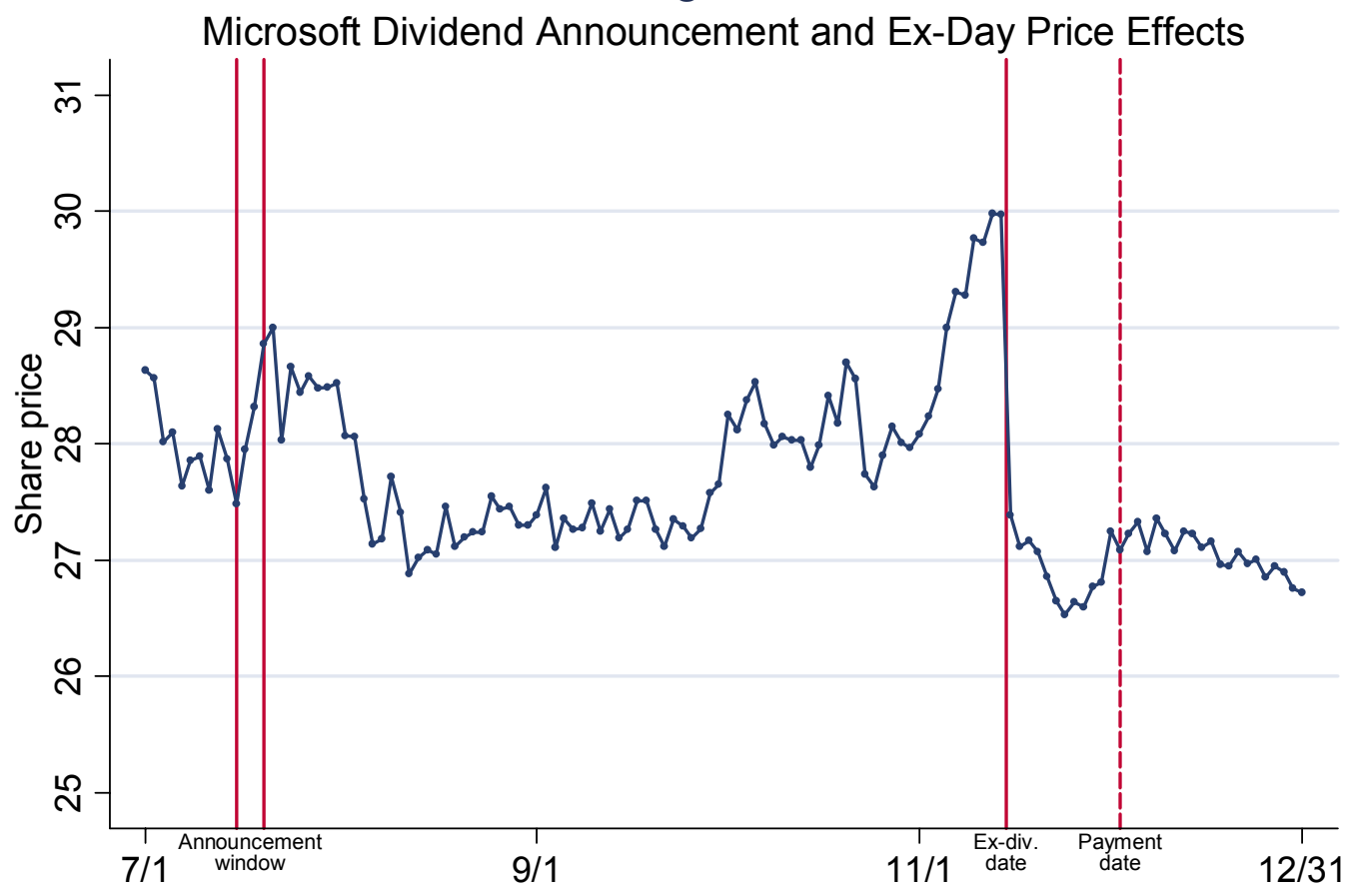

The Figure reports the daily closing prices of Microsoft shares from 7/1/2005 to 12/31/2005 from CRSP data. On July 20, Microsoft announced a doubling of its regular dividend payments as well as the payment of a very large one time special dividend of $\$ 3$ per share. The three day window around the announcement date, which is used to estimate abnormal returns, is depicted by the first two vertical lines. The ex-day for the $\$ 3$ special dividend in November 15 . The drop in price from the cum-day (November 14) to the ex-day (November 15), is depicted by the next two vertical lines. The payment date, December 2, is also depicted by a dashed line. 


\section{Figure 2}

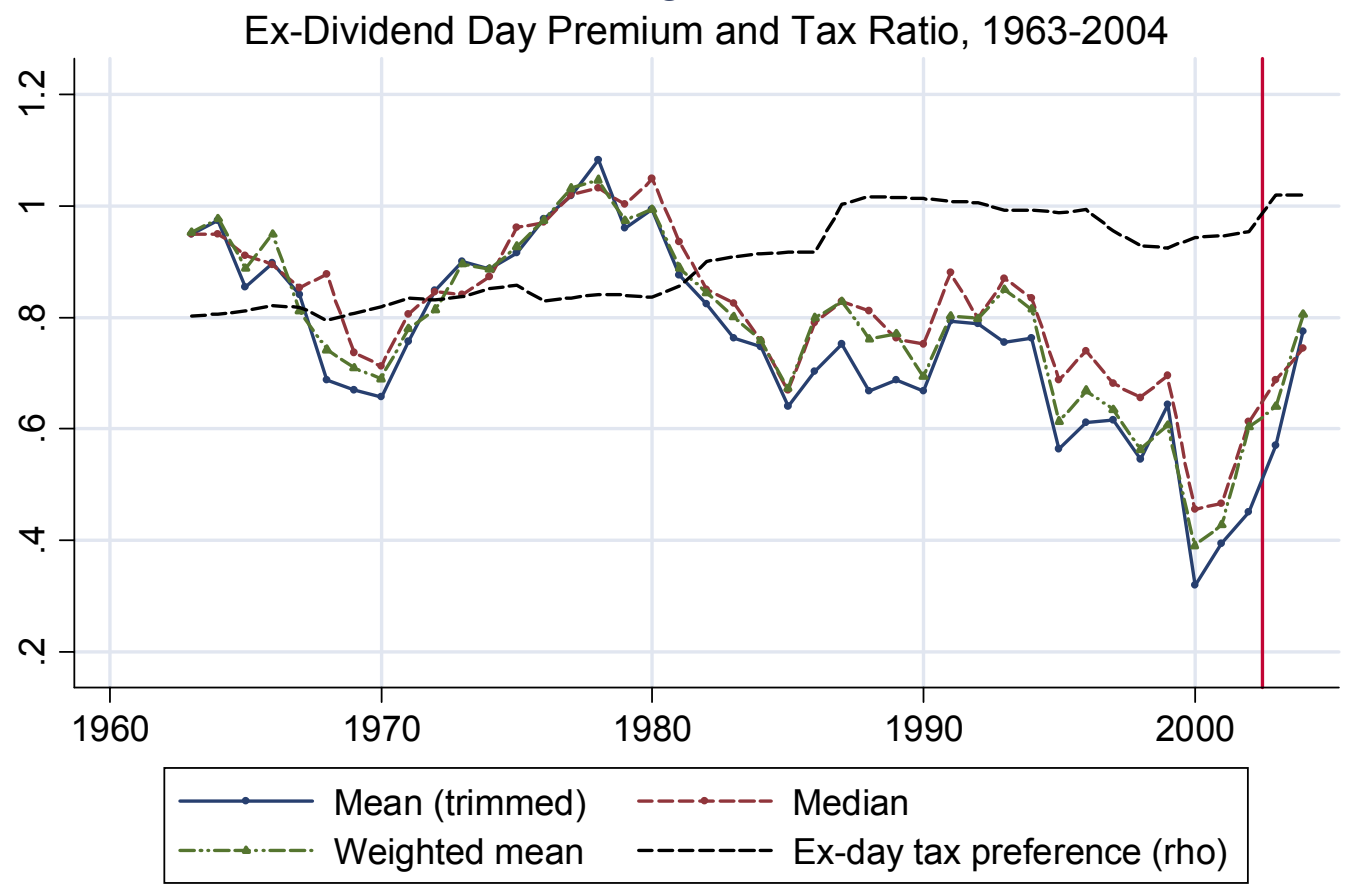

This figure depicts the tax preference ratio $\rho=\left(1-t_{d}\right) /\left(1-t_{c}\right)$ measuring the tax preference of realized capital gains over dividends for US corporate stock (weighted by ownership) from 1963 to 2004. The figure also depicts three annual time series measures of the (market adjusted) dividend premium $\Delta P / D$ for all taxable regular and special dividend payments from 1963 to 2004: 1) the mean (trimmed for the smallest $25 \%$ dividend yield events), 2 ) the dividend-yield weighted mean, 3) and the median. All four time series are displayed on Table 1. 


\section{Figure 3}

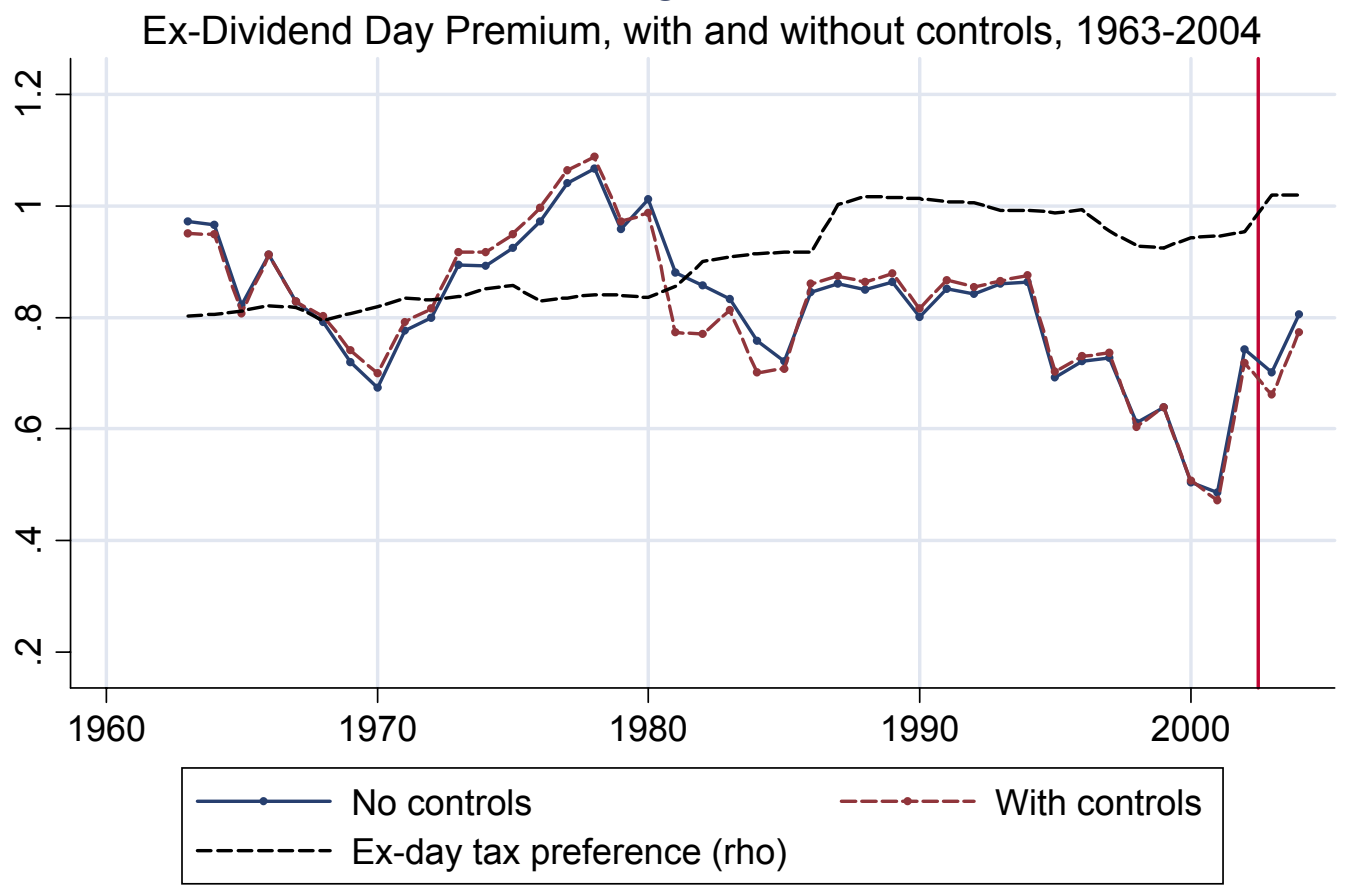

This figure depicts the ex-dividend tax preference ratio $\rho$. The figure also depicts the dividend-yield weighted mean of the premium (as in Figure 2) along with dividend-yield weighted mean of the premium controlling for the ten-year nominal interest rate and observable firm-level variables (cash, assets, liabilities, earnings, and investment) from Compustat. The latter series is obtained from a regression of the adjusted premium on a full set of year dummies and the control variables. 


\section{Figure 4}

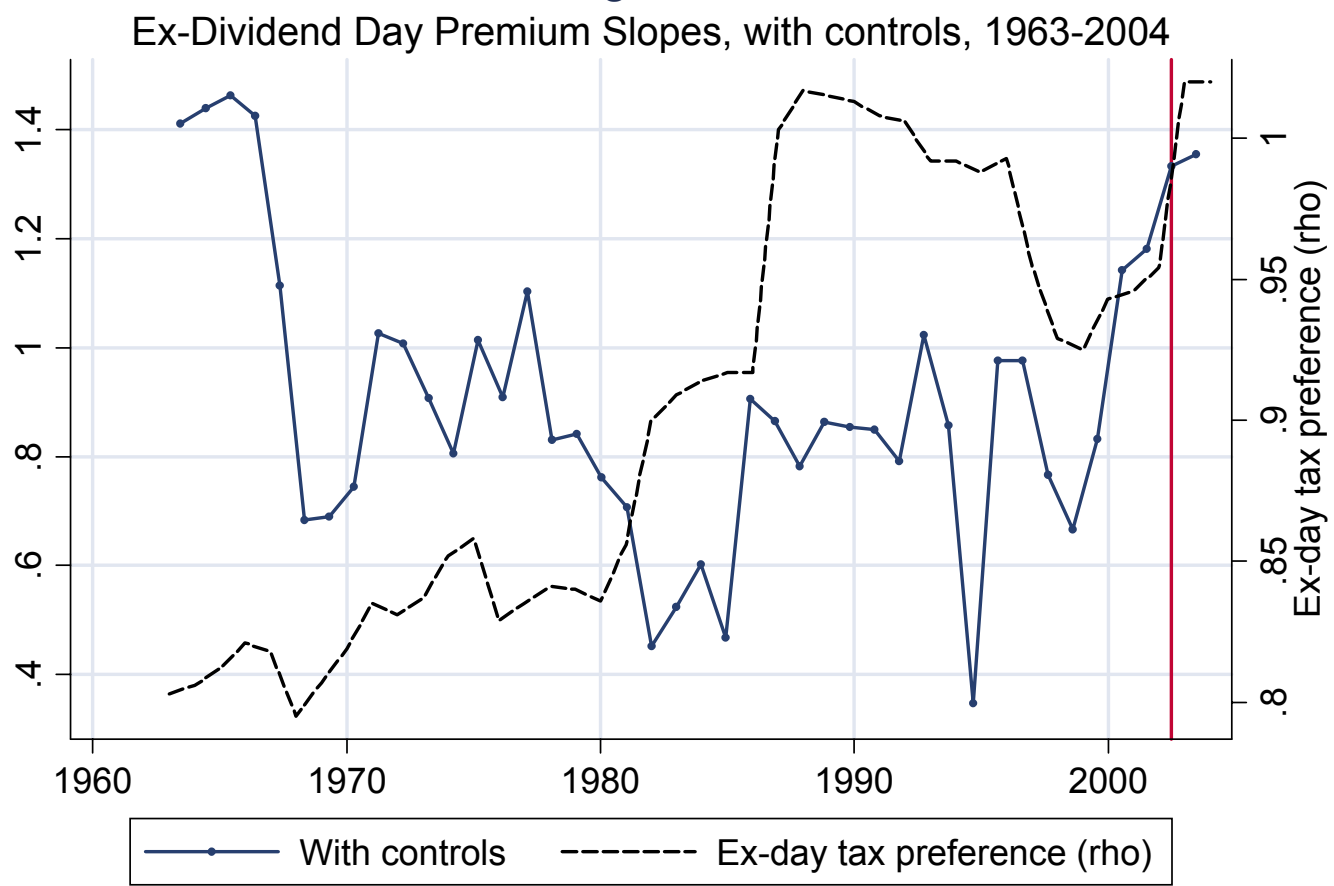

This figure depicts the ex-dividend day tax preference ratio $\rho$ (on the right sca,e). The figure also depicts the year dummy coefficients interacted with the dividend yield $D / P$ of regression equation $(\mathrm{X})$ in the text (with controls): the (adjusted) excess return around the ex-day is regressed on a full set of year dummies and year dummies interacted with the dividend yield $D / P$. The additional control variables (for the second series) are the same as in Figure 3 . 
Figure 5

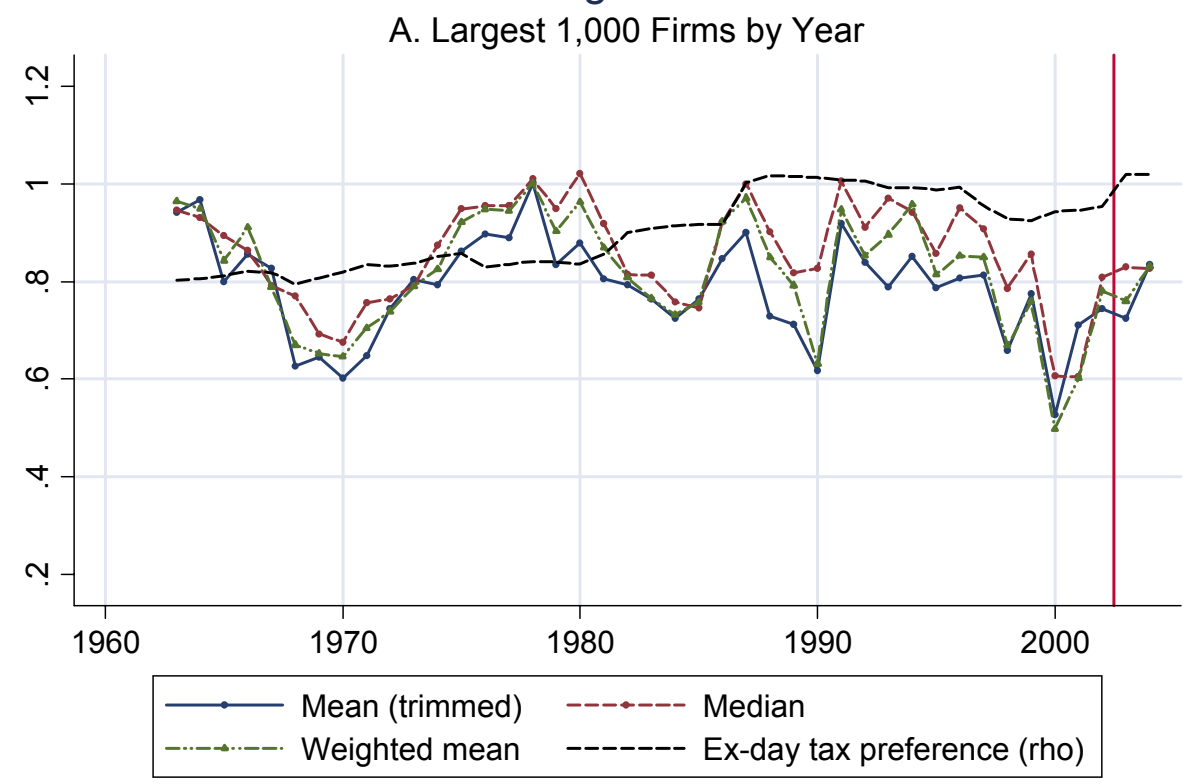

B. Consistent Sample of Firms, 1990-2004

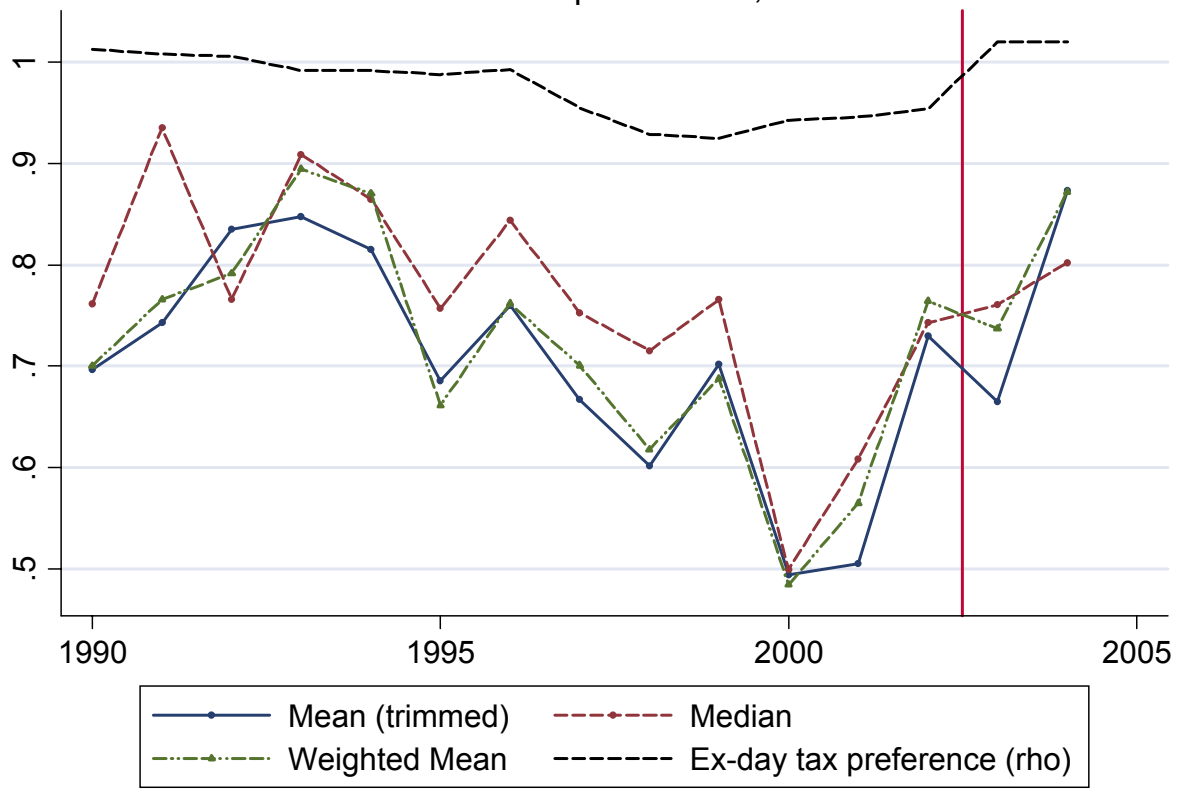

This figure depicts the tax preference ratio $\rho$ and the three annual time series measures of the (market adjusted) dividend premium $\Delta P / D$ (mean trimmed, weighted mean, and median) as in Figure 2 for alternative samples. In Panel A, the sample is restricted to the largest 1,000 firms (ranked by market capitalization) in each year. In Panel B, the sample consists in the panel data of all firms present in the CRSP data in every year from 1990 to 2004. The number of such firms is 1,402 . 


\section{Figure 6}

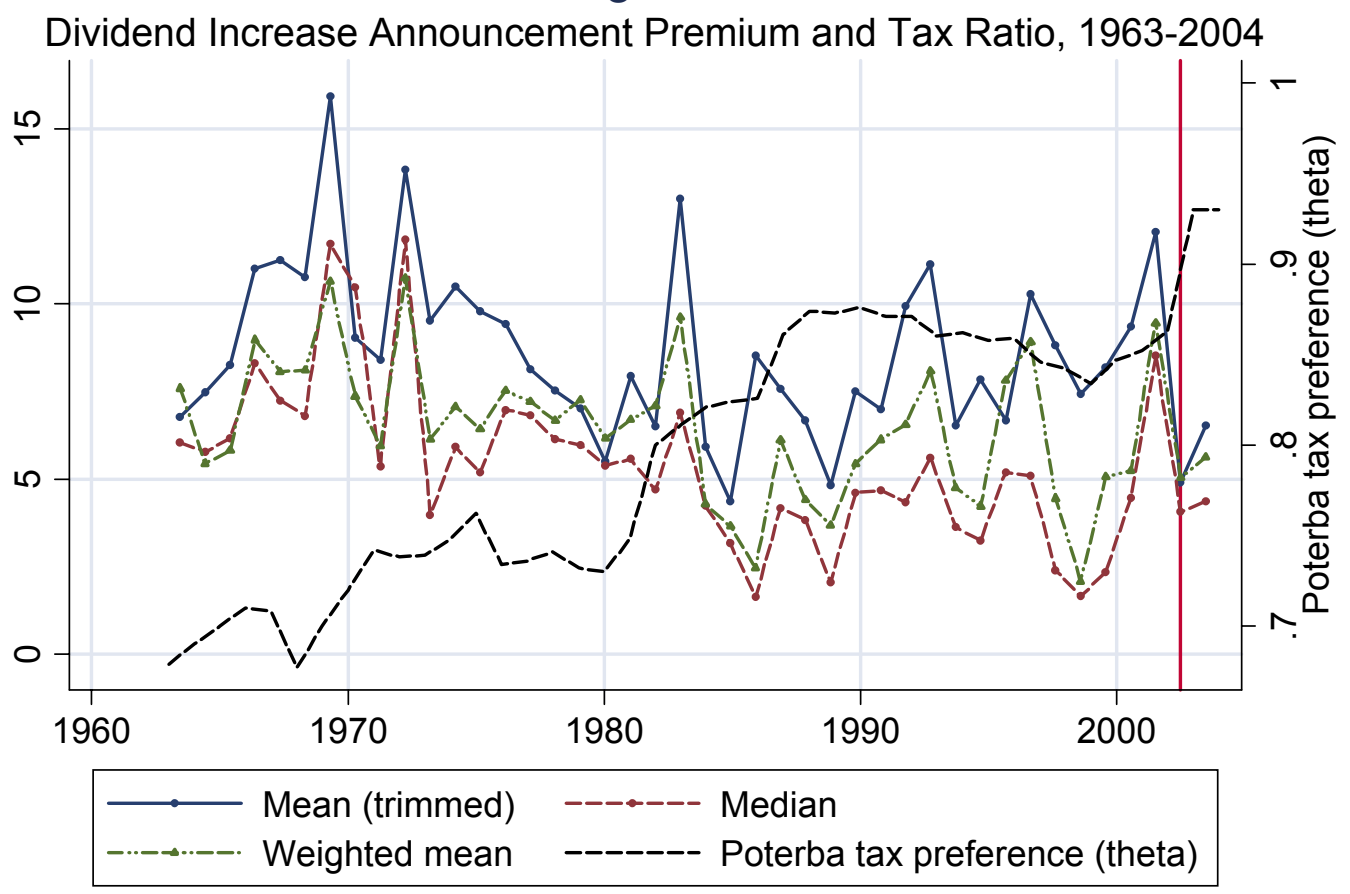

This figure depicts (on the right hand scale) the tax preference ratio $\theta=\left(1-t_{d}\right) /\left(1-t_{a c}\right)$ from Poterba (2004) which measures the tax preference of accrued capital gains over dividends for US corporate stock (weighted by ownership) from 1963 to 2004. The figure also depicts three annual time series measures of the (market adjusted) dividend increase premium $\Delta P / \Delta D$ for all regular dividend increases and initiations from 1963 to 2004: 1) the mean (trimmed for the smallest $25 \%$ dividend increase to price ratio events), 2) the weighted mean (weight is $\Delta D / P)$, and 3) the median. All four time series are displayed on Table 2. 


\section{Figure 7}

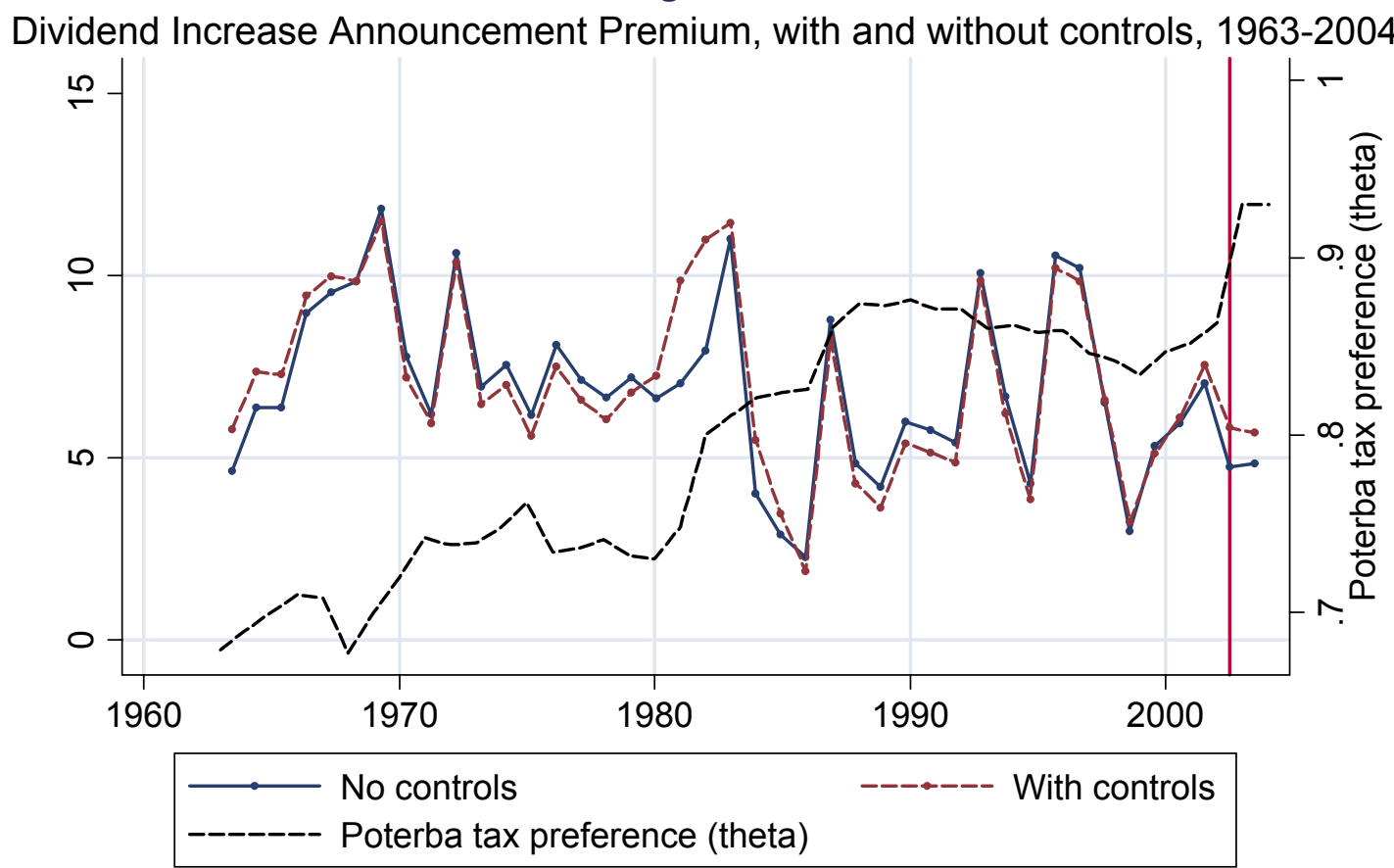

This figure depicts the Poterba (2004) tax preference ratio $\theta$ (on the right hand scale). The figure also depicts the weighted mean of the announcement premium (as in Figure 6) along with weighted mean of the announcement premium controlling for the ten-year nominal interest rate and observable firm-level variables (cash, assets, liabilities, earnings, and investment) from Compustat. The latter series is obtained from a regression of the adjusted premium on a full set of year dummies and the control variables. 


\section{Figure 8}

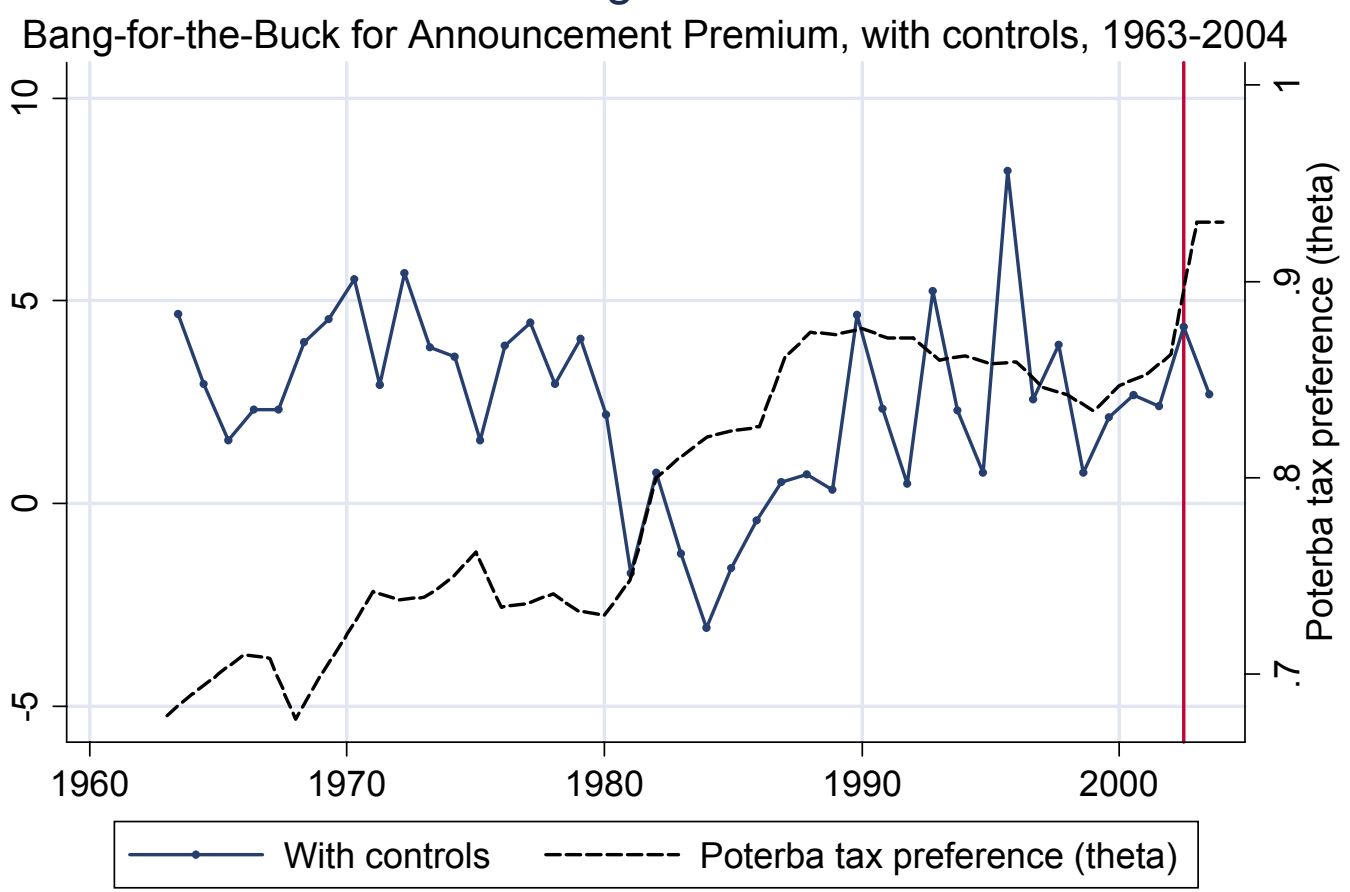

This figure depicts the Poterba (2004) tax preference ratio $\theta$ (on the right hand scale). The figure also depicts the year dummy coefficients interacted with the dividend yield increase $\Delta D / P$ of regression equation ( $\mathrm{X})$ in the text (with controls): the (adjusted) excess return around the announcement date is regressed on a full set of year dummies and year dummies interacted with the change in dividend yield $\Delta D / P$. The additional control variables (for the second series) are the same as in Figure 7. 
Table 1

Ex-Dividend Day Statistics and Results

\begin{tabular}{|c|c|c|c|c|c|}
\hline & $\begin{array}{c}(1) \\
\text { Tax-Preference } \\
(\rho) \\
\end{array}$ & $\begin{array}{c}\text { (2) } \\
\text { \# Events } \\
\end{array}$ & $\begin{array}{c}(3) \\
\text { Median } \\
\text { Premium } \\
\end{array}$ & $\begin{array}{c}(4) \\
\text { Weighted Mean } \\
\text { Premium } \\
\end{array}$ & $\begin{array}{c}(5) \\
\text { Trimmed Mean } \\
\text { Premium } \\
\end{array}$ \\
\hline 1963 & 0.80 & 4,089 & 0.95 & 0.95 & 0.95 \\
\hline 1964 & 0.81 & 4,418 & 0.95 & 0.98 & 0.97 \\
\hline 1965 & 0.81 & 4,767 & 0.91 & 0.89 & 0.85 \\
\hline 1966 & 0.82 & 5,029 & 0.89 & 0.95 & 0.90 \\
\hline 1967 & 0.82 & 5,259 & 0.85 & 0.81 & 0.84 \\
\hline 1968 & 0.80 & 4,697 & 0.88 & 0.74 & 0.69 \\
\hline 1969 & 0.81 & 5,074 & 0.74 & 0.71 & 0.67 \\
\hline 1970 & 0.82 & 4,910 & 0.71 & 0.69 & 0.66 \\
\hline 1971 & 0.84 & 4,851 & 0.81 & 0.78 & 0.76 \\
\hline 1972 & 0.83 & 4,974 & 0.85 & 0.81 & 0.85 \\
\hline 1973 & 0.84 & 5,232 & 0.84 & 0.90 & 0.90 \\
\hline 1974 & 0.85 & 5,317 & 0.87 & 0.89 & 0.89 \\
\hline 1975 & 0.86 & 5,451 & 0.96 & 0.93 & 0.91 \\
\hline 1976 & 0.83 & 5,782 & 0.97 & 0.97 & 0.98 \\
\hline 1977 & 0.84 & 6,234 & 1.02 & 1.03 & 1.02 \\
\hline 1978 & 0.84 & 6,347 & 1.03 & 1.05 & 1.08 \\
\hline 1979 & 0.84 & 6,034 & 1.00 & 0.97 & 0.96 \\
\hline 1980 & 0.84 & 6,035 & 1.05 & 0.99 & 0.99 \\
\hline 1981 & 0.86 & 5,712 & 0.94 & 0.89 & 0.88 \\
\hline 1982 & 0.90 & 5,239 & 0.85 & 0.84 & 0.82 \\
\hline 1983 & 0.91 & 5,404 & 0.83 & 0.80 & 0.76 \\
\hline 1984 & 0.91 & 5,977 & 0.76 & 0.76 & 0.75 \\
\hline 1985 & 0.92 & 6,813 & 0.67 & 0.67 & 0.64 \\
\hline 1986 & 0.92 & 7,345 & 0.79 & 0.80 & 0.70 \\
\hline 1987 & 1.00 & 7,498 & 0.83 & 0.83 & 0.75 \\
\hline 1988 & 1.02 & 7,432 & 0.81 & 0.76 & 0.67 \\
\hline 1989 & 1.02 & 7,334 & 0.76 & 0.77 & 0.69 \\
\hline 1990 & 1.01 & 6,882 & 0.75 & 0.69 & 0.67 \\
\hline 1991 & 1.01 & 6,484 & 0.88 & 0.80 & 0.79 \\
\hline 1992 & 1.01 & 6,807 & 0.80 & 0.80 & 0.79 \\
\hline 1993 & 0.99 & 7,231 & 0.87 & 0.85 & 0.76 \\
\hline 1994 & 0.99 & 7,594 & 0.83 & 0.81 & 0.76 \\
\hline 1995 & 0.99 & 8,030 & 0.69 & 0.61 & 0.56 \\
\hline 1996 & 0.99 & 8,022 & 0.74 & 0.67 & 0.61 \\
\hline 1997 & 0.96 & 7,764 & 0.68 & 0.63 & 0.62 \\
\hline 1998 & 0.93 & 6,984 & 0.66 & 0.56 & 0.55 \\
\hline 1999 & 0.93 & 7,190 & 0.70 & 0.61 & 0.64 \\
\hline 2000 & 0.94 & 6,058 & 0.46 & 0.39 & 0.32 \\
\hline 2001 & 0.95 & 5,661 & 0.47 & 0.43 & 0.39 \\
\hline 2002 & 0.95 & 5,905 & 0.61 & 0.60 & 0.45 \\
\hline 2003 & 1.02 & 6,147 & 0.69 & 0.64 & 0.57 \\
\hline 2004 & 1.02 & 6,347 & 0.74 & 0.81 & 0.77 \\
\hline Std Dev & 0.08 & & 0.14 & 0.15 & 0.17 \\
\hline Total & 0.90 & 256,360 & 0.81 & 0.79 & 0.76 \\
\hline
\end{tabular}

Column (1) reports the tax preference ratio $\rho=(1-\mathrm{td}) /(1-\mathrm{tc})$ measuring the tax preference of realized capital gains over dividends for US corporate stock (weighted by ownership) from 1963 to 2004 . This ratio is constructed based on the data appendix from Poterba (2004).

Column (2) reports the annual number of ex-dividend day in the sample for all taxable regular and special dividends. Columns (3) to (5) report the corresponding time series measures of the (market adjusted) dividend premium $\Delta \mathrm{P} / \mathrm{D}$. Column (3) reports the median. Column (4) reports the dividend-yield weighted mean. Column (5) reports the mean (trimmed for the smallest $25 \%$ dividend yield events). 
Table 2

Dividend Increase Announcements Statistics and Results

\begin{tabular}{|c|c|c|c|c|c|}
\hline & $\begin{array}{c}(1) \\
\text { Tax-Preference } \\
(\theta) \\
\end{array}$ & $\begin{array}{r}\text { (2) } \\
\text { \# Events } \\
\end{array}$ & $\begin{array}{c}(3) \\
\text { Median } \\
\text { Premium } \\
\end{array}$ & $\begin{array}{c}(4) \\
\text { Weighted Mean } \\
\text { Premium } \\
\end{array}$ & $\begin{array}{c}(5) \\
\text { Trimmed Mean } \\
\text { Premium } \\
\end{array}$ \\
\hline 1963 & 0.68 & 307 & 6.05 & 7.59 & 6.78 \\
\hline 1964 & 0.69 & 531 & 5.78 & 5.45 & 7.47 \\
\hline 1965 & 0.70 & 679 & 6.18 & 5.83 & 8.26 \\
\hline 1966 & 0.71 & 667 & 8.31 & 8.98 & 11.00 \\
\hline 1967 & 0.71 & 490 & 7.25 & 8.07 & 11.25 \\
\hline 1968 & 0.68 & 390 & 6.80 & 8.11 & 10.78 \\
\hline 1969 & 0.70 & 368 & 11.71 & 10.65 & 15.93 \\
\hline 1970 & 0.72 & 293 & 10.48 & 7.37 & 9.04 \\
\hline 1971 & 0.74 & 245 & 5.36 & 5.95 & 8.40 \\
\hline 1972 & 0.74 & 491 & 11.84 & 10.73 & 13.82 \\
\hline 1973 & 0.74 & 1,119 & 3.98 & 6.13 & 9.53 \\
\hline 1974 & 0.75 & 932 & 5.91 & 7.07 & 10.51 \\
\hline 1975 & 0.76 & 707 & 5.18 & 6.43 & 9.80 \\
\hline 1976 & 0.73 & 1,264 & 6.98 & 7.53 & 9.44 \\
\hline 1977 & 0.74 & 1,397 & 6.83 & 7.21 & 8.13 \\
\hline 1978 & 0.74 & 1,388 & 6.14 & 6.68 & 7.54 \\
\hline 1979 & 0.73 & 1,270 & 5.98 & 7.27 & 7.03 \\
\hline 1980 & 0.73 & 1,077 & 5.40 & 6.17 & 5.51 \\
\hline 1981 & 0.75 & 902 & 5.57 & 6.70 & 7.94 \\
\hline 1982 & 0.80 & 645 & 4.70 & 7.09 & 6.51 \\
\hline 1983 & 0.81 & 707 & 6.89 & 9.61 & 13.01 \\
\hline 1984 & 0.82 & 868 & 4.24 & 4.28 & 5.92 \\
\hline 1985 & 0.82 & 1,045 & 3.16 & 3.65 & 4.36 \\
\hline 1986 & 0.83 & 1,066 & 1.64 & 2.46 & 8.53 \\
\hline 1987 & 0.86 & 1,099 & 4.17 & 6.12 & 7.58 \\
\hline 1988 & 0.87 & 1,261 & 3.83 & 4.41 & 6.69 \\
\hline 1989 & 0.87 & 1,311 & 2.06 & 3.68 & 4.83 \\
\hline 1990 & 0.88 & 1,047 & 4.61 & 5.44 & 7.52 \\
\hline 1991 & 0.87 & 825 & 4.68 & 6.13 & 6.99 \\
\hline 1992 & 0.87 & 963 & 4.35 & 6.56 & 9.94 \\
\hline 1993 & 0.86 & 1,139 & 5.61 & 8.10 & 11.13 \\
\hline 1994 & 0.86 & 1,230 & 3.63 & 4.75 & 6.52 \\
\hline 1995 & 0.86 & 1,371 & 3.25 & 4.23 & 7.85 \\
\hline 1996 & 0.86 & 1,342 & 5.20 & 7.82 & 6.69 \\
\hline 1997 & 0.85 & 1,267 & 5.09 & 8.91 & 10.28 \\
\hline 1998 & 0.84 & 1,123 & 2.40 & 4.45 & 8.81 \\
\hline 1999 & 0.83 & 1,092 & 1.65 & 2.08 & 7.42 \\
\hline 2000 & 0.85 & 939 & 2.35 & 5.08 & 8.19 \\
\hline 2001 & 0.85 & 801 & 4.46 & 5.24 & 9.36 \\
\hline 2002 & 0.86 & 878 & 8.53 & 9.46 & 12.07 \\
\hline 2003 & 0.93 & 1,222 & 4.06 & 5.04 & 4.89 \\
\hline 2004 & 0.93 & 1,193 & 4.37 & 5.63 & 6.52 \\
\hline Std Dev & 0.07 & & 2.34 & 1.99 & 2.46 \\
\hline Total & 0.80 & 38,951 & 5.40 & 6.43 & 8.57 \\
\hline
\end{tabular}

Column (1) reports the tax preference ratio $\theta=(1-\mathrm{td}) /(1-\mathrm{tc})$ measuring the tax preference of accrued capital gains over dividends for US corporate stock (weighted by ownership) from 1963 to 2004. This ratio is from Poterba (2004).

Column (2) reports the annual number of regular taxable dividend nominal increases or initiations in the sample. Columns (3) to (5) report the corresponding time series measures of the (market adjusted) dividend increase premium $\Delta \mathrm{P} / \Delta \mathrm{D}$. Column (3) reports the median. Column (4) reports the weighted mean (weight is $\Delta \mathrm{D} / \mathrm{P}$ ). Column (5) reports the mean (trimmed for the smallest $25 \%$ dividend increase to price ratio events). 
Table 3a

2003 Tax Episode Analysis: Ex-dividend Day Premia

\begin{tabular}{lccc}
\hline \hline & $(1)$ & $(2)$ & $(3)$ \\
& Pre-reform & Post-reform & Change \\
& 0.95 & 1.02 & 0.07 \\
$\begin{array}{l}\text { Ex-day Tax Preference } \\
\text { Ratio }(\rho)\end{array}$ & & & \\
Median Premium & 0.61 & 0.74 & 0.13 \\
& $(0.04)$ & $(0.03)$ & $(0.05)$ \\
Weighted Mean Premium & 0.60 & 0.81 & 0.20 \\
& $(0.06)$ & $(0.05)$ & $(0.08)$ \\
Trimmed Mean Premium & 0.45 & 0.77 & 0.32 \\
& $(0.06)$ & $(0.05)$ & $(0.08)$ \\
& & & \\
\hline
\end{tabular}

Notes: Pre-reform refers to dividend paid out in 2002 while post reform refers to dividends paid out in 2004. The standard errors in column (3) are estimated from a median, weighted OLS, and simple OLS regressions respectively.

Table 3b

2003 Tax Episode Analysis: Dividend Increase Announcements

\begin{tabular}{lccc}
\hline \hline & $\begin{array}{c}(1) \\
\text { Pre-reform }\end{array}$ & $\begin{array}{c}(2) \\
\text { Post-reform }\end{array}$ & $\begin{array}{c}(3) \\
\text { Change }\end{array}$ \\
& 0.86 & 0.93 & 0.07 \\
$\begin{array}{l}\text { Poterba Tax Preference } \\
\text { Ratio }(\theta)\end{array}$ & & & \\
Median Premium & 8.53 & 4.37 & -4.16 \\
& $(1.83)$ & $(1.11)$ & $(2.01)$ \\
Weighted Mean Premium & 9.46 & 5.63 & -3.83 \\
& $(2.37)$ & $(1.29)$ & $(2.56)$ \\
Trimmed Mean Premium & 12.07 & 6.52 & -5.54 \\
& $(2.94)$ & $(1.76)$ & $(3.22)$ \\
\hline
\end{tabular}

Notes: Pre-reform refers to dividend paid out in 2002 while post reform refers to dividends paid out in 2004. The standard errors in column (3) are estimated from a median, weighted OLS, and simple OLS regressions respectively. 
Table 4a

Ex-Dividend Day Regression Results: Dependent Variable $=\Delta P / D$

\begin{tabular}{lccc}
\hline \hline & $(1)$ & $(2)$ & $(3)$ \\
& & & \\
& $1980-1985$ & $1985-1989$ & $2000-2004$ \\
\cline { 2 - 4 } Tax Preference $(\rho)$ & -2.742 & 0.666 & 1.323 \\
& $(0.550)$ & $(0.611)$ & $(1.477)$ \\
R-squared & 0.001 & 0.001 & 0.001 \\
\hline
\end{tabular}

Notes: All regressions are weighted by dividend yield. Interest rate controls include the level and square of the ten-year U.S. Treasury yield. Firm controls include lagged levels of cash, assets, liabilities, earnings, and investment.

\section{Table 4b}

Ex-Dividend Day Regression Results: Dependent Variable $=\Delta \mathrm{P} / \mathrm{P}$

\begin{tabular}{lccc}
\hline \hline & $(1)$ & $(2)$ & $(3)$ \\
& & & \\
& $1980-1985$ & $1985-1989$ & $2000-2004$ \\
\cline { 2 - 4 } Tax Preference $(\rho)$ & 0.006 & -0.001 & 0.006 \\
& $(0.009)$ & $(0.005)$ & $(0.009)$ \\
Dividend Yield & 3.627 & 0.382 & 0.454 \\
& $(0.619)$ & $(0.432)$ & $(0.453)$ \\
Dividend Yield * $\rho$ & -3.097 & 0.578 & 0.460 \\
& $(0.703)$ & $(0.437)$ & $(0.461)$ \\
R-squared & 0.064 & 0.317 & 0.346 \\
\hline
\end{tabular}

Notes: Interest rate controls include the level and square of the ten-year U.S. Treasury yield. Firm controls include lagged levels of cash, assets, liabilities, earnings, and investment. 
Table 5a

Dividend Increase Announcements Regression Results: Dependent Variable $=\Delta P / \Delta D$

\begin{tabular}{lccc}
\hline \hline & $(1)$ & $(2)$ & $(3)$ \\
& & & \\
& $1980-1985$ & $1985-1989$ & $2000-2004$ \\
\cline { 2 - 4 } Tax Preference $(\theta)$ & -16.954 & 36.993 & -61.576 \\
& $(14.515)$ & $(27.106)$ & $(51.408)$ \\
R-squared & 0.001 & 0.003 & 0.002 \\
\hline
\end{tabular}

Notes: All regressions are weighted by the change in the nominal dividend amount divided by the preannouncement share price. Interest rate controls include the level and square of the ten-year U.S. Treasury yield. Firm controls include lagged levels of cash, assets, liabilities, earnings, and investment.

Table 5b

Dividend Increase Announcements Regression Results: Dependent Variable $=\Delta P / P$

\begin{tabular}{lccc}
\hline \hline & $(1)$ & $(2)$ & $(3)$ \\
& $1980-1985$ & $1985-1989$ & $2000-2004$ \\
\cline { 2 - 4 } Tax Preference $(\theta)$ & 0.002 & -0.081 & -0.050 \\
& $(0.022)$ & $(0.037)$ & $(0.046)$ \\
$\Delta$ Dividend Yield & 26.231 & -31.405 & 3.225 \\
& $(6.565)$ & $(8.052)$ & $(10.557)$ \\
$\Delta$ Dividend Yield * $\theta$ & -30.754 & 37.631 & -2.376 \\
& $(8.277)$ & $(9.529)$ & $(11.712)$ \\
R-squared & 0.020 & 0.008 & 0.032 \\
\hline
\end{tabular}

Notes: Interest rate controls include the level and square of the ten-year U.S. Treasury yield. Firm controls include lagged levels of cash, assets, liabilities, earnings, and investment. 